\title{
ECLETICA
}

www.scielo.br/eq

Volume 31, número 4, 2006

\section{Spectrophotometric study of the chromium(III)/azide system in the ultraviolet region and its analytical application}

\author{
${ }^{*}$ L. M. Lourenço, F. G. Martins, V. R. Balbo, A. C. Pimenta, J. R. M. Castro, J. F. Andrade \\ Departamento de Química, Faculdade de Filosofia, Ciências e Letras de Ribeirão Preto - USP, Av. Bandeirantes, 3900 \\ (Campus da USP),14040-901, Ribeirão Preto, SP, Brazil.
}

\begin{abstract}
A sensitive and alternative method for the spectrophotometric determination of chromium(III) based on the formation of chromium(III)/azide complexes was established by investigating a new band in the ultraviolet region. The best experimental conditions for the analytical determination of this metallic ion were: ligand and perchloric acid analytical concentration $=493$ and $12.0 \mathrm{mmol} \mathrm{L}-1$, respectively; aqueous medium; $\mathrm{T}=25.0^{\circ} \mathrm{C}$; contact time $=1$ hour. The maximum molar absorptivity coefficient occurred at $287 \mathrm{~nm}$ (average $1.481 \pm 0.008 \times 10^{4} \mathrm{~L} \mathrm{~mol}^{-1} \mathrm{~cm}^{-1}$ ), leading to the determination of metal ion concentrations one hundred times lower than the ones formerly determined in the visible region. The system obeys Beer's Law and is suitable for chromium determination in the $0.702-2.81 \mathrm{mg} \mathrm{L}^{-1}$ concentration range $(15-65 \% \mathrm{~T}, 1.00 \mathrm{~cm}$-width quartz cells). Analytical applications of the current method were tested with a nutritional supplement containing chromium. Results were compared with those obtained with atomic absorption spectrometry.
\end{abstract}

Keywords: Chromium; azide; spectrophotometry; complexes.

\section{Introduction}

Azide and thiocyanate complexes of several metallic cations have been systematically studied in our laboratories with a view to understanding their coordination chemistry (equilibria) [1-3] and developing their analytical applications [4-12]. There is great analogy between the azide and the thiocyanate ligands (pseudohalides), since they develop the same red color in acid solution containing iron(III). Some of our studies have been of a comparative character, showing that the azide system is much more stable than the thiocyanate one. As part of these continuous investigations, it is expected that chromium(III) will form complexes with the pseudohalide azide in the same way that other transition metals such as iron, copper, nickel, and cobalt.
In the literature, studies carried out by Sherif and Orab $[13,14]$ in aqueous medium using the visible region revealed the existence of a relationship between the several free ligand (azide) and chromium(III) concentrations with absorbance, producing colorings ranging from violet to green. Moreover, the solution was reported to develop blue tones under great ligand excess. In the work of Templeton \& King [15], the effect of perchloric acid concentration on the formation of pentaaquoazidochromium(III) compounds was also reported. The main objective of the latter work was to determine the kinetics and equilibrium of this system. The authors reported maximum absorption at $270 \mathrm{~nm}$, under highly acid concentrations, which was attributed to interactions between azidochromium(III) and/or hydrogen azidochromium(III) and the perchlorate ion. The 
results of a quantitative treatment in the ultraviolet region obtained by these authors were unsuccessful. Ever since, this region of the spectrum has been abandoned for investigation of the chromium(III)/azide system.

In the present work, optimization of the experimental conditions for the study of the chromium(III)/azide system in the ultraviolet region has been accomplished. The quantification of this metal ion complex considering its maximum absorption in the ultraviolet region has also been carried out in real samples.

The proposed method was tested for a nutritional supplement sample, showing good agreement with results obtained by means of atomic absorption spectroscopy.

\section{Experimental details}

\section{Apparatus and reagents}

Spectrophotometric measurements were accomplished on a UV-Visible Beckman DU-70 spectrophotometer, using a quartz cell of $1.00 \mathrm{~cm}$ path length. A Shimadzu AA-680 atomic absorption spectrophotometer was used for reference analyses, in order to compare the results obtained through both methods.

Potentiometric titrations were accomplished on a Micronal B-374 pHmeter, using 5.00 $\mathrm{mL}$ Metrohm piston burets. A Tecnal TE-184 thermostatic bath was used for studies on temperature effect, as well as to control the temperature after the establishment of the ideal conditions. For treatment of the analyzed samples, a Corning PC-320 hotplate was employed.

Deionized water (with conductivity inferior to $1 \mu \mathrm{S}$ ) was used in the preparation of all samples and solutions. All reagents were of analytical purity grade.

The sodium azide solution $\left(3.52 \mathrm{~mol} \mathrm{~L}^{-1}\right)$ was standardized by potentiometric titration with silver nitrate, using a combined electrode (reference electrode $\mathrm{Ag} / \mathrm{AgCl}$ and silver wire as indicator). Perchloric acid (0.302 $\left.\mathrm{mol} \mathrm{L}^{-1}\right)$ was potentiometrically standardized with a standardized solution of sodium hydroxide, which had been previously adjusted with phthalate potassium acid. The chromium(III) perchlorate solution $\left(2.023 \mathrm{mmol} \mathrm{L}^{-1}, \mathrm{pH} \cong\right.$
1) was acidified with perchloric acid and was standardized by means of the spectrophotometric method of chromium in steel determination using potassium dichromate salt purchased from Merck. The standardization measurements were accomplished at $438 \mathrm{~nm}$. AR grade organic solvents (Acetone - Merck (ACS, ISO); Tetrahydrofuran Merck (ACS); 1-Propanol Vetec; Ethanol - Merck; Methanol - Merck; Acetonitrile - Vetec) were used without any prior treatment. For the opening of the nutritional supplement samples, nitric acid 65\% Merck and Perchloric acid 70\% Merck were used. The sodium tartrate employed was PA grade and it was purchased from Carlo Erba.

All the saline solutions, generally used as their respective nitrates or sodium salts, for the interference study were prepared in the concentration of $0.20 \mathrm{~mol} \mathrm{~L}^{-1}$, and diluted as appropriate.

\section{Treatment of nutritional supplement samples}

A nutritional supplement sample containing chromium was tested. It was purchased at drugstores in its commercially available pure salt form. The sample was manufactured by Albion $^{\circledR}$ Laboratories, and Cromo Chelavite ${ }^{\circledR}$ 's was its trade name (Chromium Dinicotinate Glycinate), which is also known as chromium chelate.

According to the manufacturing laboratories, the amount of chromium present in the nutritional supplement containing chromium chelate was $2.5 \%$ in mass.

The mass of the samples were weighed using an analytical balance and it had been previously established so as to obtain a chromium concentration of approximately $1.0 \mathrm{mmol} \mathrm{L}^{-1}$ in a volumetric flask of $100 \mathrm{~mL}$ after suitable treatment.

The procedure was accomplished inside an exhaustion chapel. The chapel was cleaned in a way that no other organic reagent, paper, rubber, or any other substances incompatible with perchloric acid were present.

Concentrated nitric acid and (ca. $10 \mathrm{~mL}$ ) concentrated perchloric acid (ca. $15 \mathrm{~mL}$ ) were carefully added to an erlenmeyer containing the sample to be analyzed. This erlenmeyer was then placed on a heating-plate, and boiling and additions of water were carried out to allow the vaporization release of nitric acid. Boiling was done with a funnel present in the erlenmeyer mouth to avoid possible sample 
loss, and it was performed until the release of dense smoke was observed. At this point, the temperature of the heating plate was immediately decreased so that mild boiling was obtained. This was done to avoid the release of steam for as long as 5 minutes, ensuring chromium oxidation. The sample was then quantitatively transferred to a $100 \mathrm{~mL}$ volumetric flask and the volume was completed with deionized water. To facilitate understanding, this sample will be called the Supplement Sample Stock. Aliquots of such Supplement Sample Stock were pipetted into $25 \mathrm{~mL}$ volumetric flasks. For the preparation of the final sample in these volumetric flasks, chromium(VI) was reduced to chromium(III) with the addition of some drops of hydrogen peroxide (5 volumes or less). The excess of this reagent was 1.5 times the quantity necessary to discolor the yellow samples. After complete reduction, sodium hydroxide was slowly added in a predetermined amount under vigorous stirring, so as to neutralize the excess acid.

To determine the exact amount of sodium hydroxide that should be added, an aliquot of the Supplement Sample Stock was taken and hydrogen peroxide was added to it. Next, excess sodium tartrate was added in the salt form, and the resulting sample was titrated with sodium hydroxide. Knowing the concentration of perchloric acid present in the Supplement Sample Stock, the excess acid contained in the pipetted volume was then neutralized in the $25 \mathrm{~mL}$ volumetric flask, in a way that the resulting solution contained a concentration of $12.0 \mathrm{mmol} \mathrm{L}^{-1}$ of the remaining acid. The sample that resulted from such sample treatment will be called Treated Supplement from this point.

After such treatment, the ligand still had to be added at an ideal concentration, temperature, and contact (reaction) time so that the flask could finally be filled to the mark.

The presence of sodium tartrate throughout the titration was necessary to avoid formation of chromium(III) hydroxide, which could affect the alkalimetric titration.

\section{Results and Discussion}

Several factors such as acidity, ligand concentration, temperature, and contact time affect the formation of the complex species (absorbance values) in the case of the chromium(III)/azide system. Under the best acid and ligand concentrations, the maximum absorption occurs at $287 \mathrm{~nm}$, being this band more sensitive than the visible one located between 400 and $700 \mathrm{~nm}$, which was used in the work of Sherif and Orab [14]. It has also been noticed [16] that, although the azide ligand also absorbs in the ultraviolet region, such absorption is limited to areas around $230 \mathrm{~nm}$ (under the present conditions). The absorption of azide at $287 \mathrm{~nm}$ is weak, thus allowing spectrophotometric measurements for the chromium(III)/azide system at low concentrations in the ultraviolet region.

Measurements at $287 \mathrm{~nm}$ were only carried out in this work after optimization of the conditions previously used by Sherif [13] in the visible region, when factors such as acidity, ligand concentration, nature and concentration of solvent, temperature and contact time were investigated too. After this optimization [16], it was possible to notice that the same conditions considered ideal in the visible region could be employed in the ultraviolet region, leading to the determination of metal ion concentrations a hundred times lower than the ones determined in the former region.

One of the first problems faced with this system concerned the strong turbidity observed upon metal (chromium) addition to the ligand (azide). This happens probably due to metal hydrolysis or to the insolubility of the formed species. Perchloric acid was thus added to the samples to overcome this problem, because it has low coordination ability, offering no competition to the azide ligand. Because $\mathrm{HN}_{3}$ is a weak acid $\left(\mathrm{p} K_{\mathrm{a}}=4.65\right)$ [17], it was assumed that all the added $\mathrm{HClO}_{4}$ led to the formation of hydrazoic acid. In this way, the free ligand concentration, $\left[\mathrm{N}_{3}{ }^{-}\right]$, was approximately equal to the analytical concentration of the added ligand, $\mathrm{CN}_{3}{ }^{-}$, minus the concentration of added perchloric acid.

Fig.1 shows the effect of acidity on the spectrum of the system in aqueous medium, at a free ligand concentration of $200 \mathrm{mmol} \mathrm{L}^{-1}$ and fixed contact time and temperature. Acid concentrations lower than $10.0 \mathrm{mmol} \mathrm{L}^{-1}$ was not used, allowing the $\mathrm{pH}$ to remain below 6.0 for the formed buffer solution $\left(\mathrm{HN}_{3} / \mathrm{NaN}_{3}\right)$. The most promising acidity condition was $10.0 \mathrm{mmol} \mathrm{L}^{-1}$, 
and the acidity condition employed here was 12.0 mmol L-1 for practical reasons.

The behavior observed in Fig.1 can be explained by the fact that there was more formation of $\mathrm{HN}_{3}$ (weak acid) at higher acid concentrations and, consequently, there was lower availability of the free ligand to form the absorbent complexes.

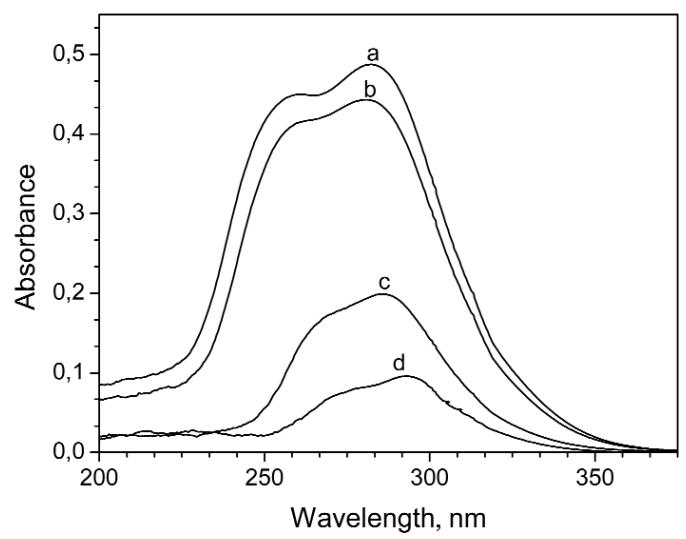

Figure 1. Effect of the acidity on the spectrum of the

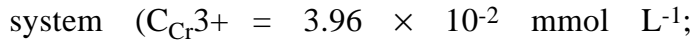
[] $=200 \mathrm{mmol} \mathrm{L}^{-1} ; \mathrm{CHClO}_{4} \mathrm{mmol} \mathrm{L}^{-1}=$ variable: (a) $=10.0, \quad(\mathrm{~b})=20.0, \quad$ (c) $=100$ and $(\mathrm{d})=200 ; \mathrm{T}=25.0^{\circ} \mathrm{C} ; \mathrm{t}=1$ hour; Sample $=$ Blank + Metal; Blank = Acid + Ligand).

Fig.2 shows the effect of the analytical concentration of the ligand on the spectrum of the system at constant chromium(III) concentration and fixed acidity $\left(12.0 \mathrm{mmol} \mathrm{L}^{-1}\right)$. A small bathochromic effect could be noticed with increasing ligand concentration. Azide analytical concentrations higher than $500 \mathrm{mmol} \mathrm{L}^{-1}$, as seen at $\mathrm{A}_{\max }$ values (maximum absorbance), did not lead to a significant increase in absorbance, so this limit was fixed. The complete saturation between metal and ligand only happened at ligand concentrations of about $900 \mathrm{mmol} \mathrm{L}^{-1}$, which was considered excessive. So, the concentration of $500 \mathrm{mmol} \mathrm{L}^{-1}$ was chosen as the most promising one for the accomplishment of the measurements. For analytical simplicity (pipetting), a ligand analytical concentration of $493 \mathrm{mmol} \mathrm{L}^{-1}$ was chosen to continue the studies.

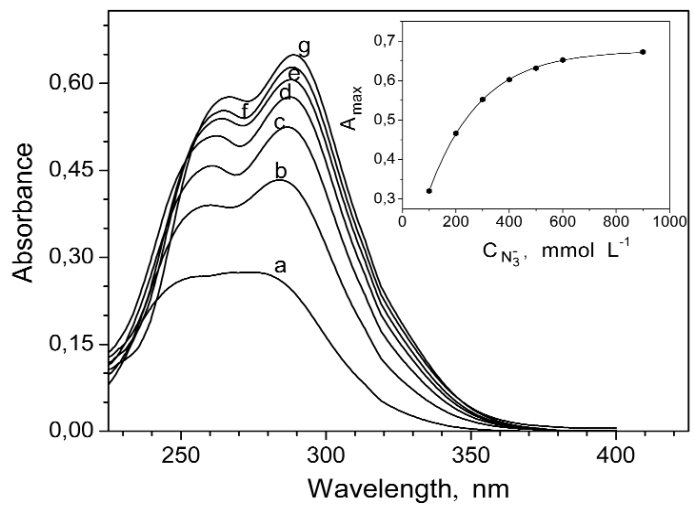

Figure 2. Effect of the ligand analytical concentration on the spectrum of the system $\left(\mathrm{C}_{\mathrm{Cr}}{ }^{3+}=3.96 \times\right.$ $10^{-2} \mathrm{mmol} \mathrm{L}^{-1} ; \mathrm{T}=25.0^{\circ} \mathrm{C} ; \mathrm{CHClO}_{4}=12.0 \mathrm{mmol} \mathrm{L}^{-}$ $1 ; \mathrm{CN}_{3}{ }^{-} \mathrm{mmol} \mathrm{L}^{-1}=$ variable: $(\mathrm{a})=100,(\mathrm{~b})=200$, (c) $=300,(\mathrm{~d})=400,(\mathrm{e})=500,(\mathrm{f})=600,(\mathrm{~g})=900 ; \mathrm{t}=$ 1 hour; Sample $=$ Blank + Metal; Blank $=$ Acid + Ligand).

Initially, a study of the influence of different solvents (acetone, tetrahydrofuran, methanol, ethanol, and propanol) on the spectrum of the chromium(III)/azide system was carried out for a concentration of $60 \%(\mathrm{v} / \mathrm{v})$. Generally, the solvation effect increased complex formation, increasing the sensitivity of the spectrophotometric tech-

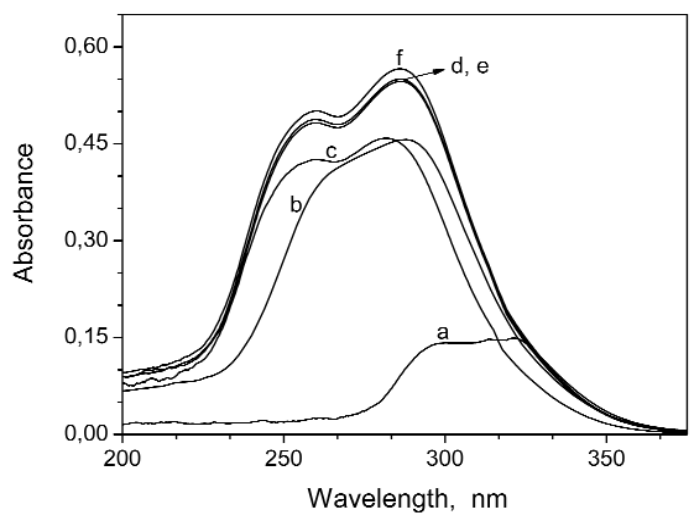

Figure 3. Effect of some solvents on the system spectrum $\left(\mathrm{C}_{\mathrm{Cr}^{3}}{ }^{3+}=3.96 \times 10^{-2} \mathrm{mmol} \mathrm{L}^{-1} ; \mathrm{CN}_{3^{-}}=200\right.$ $\mathrm{mmol} \mathrm{L}-1 ; \mathrm{CHClO}_{4}=12.0 \mathrm{mmol} \mathrm{L}^{-1} ; \mathrm{C}_{\text {solvent }}=60 \%$ $(\mathrm{v} / \mathrm{v}):(\mathrm{a})=$ acetone,$(\mathrm{b})=$ tetrahydrofuran, $(\mathrm{c})=$ water, (d) = methanol, (e) = ethanol, (f) = propanol; $\mathrm{T}=25.0$ ${ }^{\circ} \mathrm{C} ; \mathrm{t}=1$ hour; Sample $=$ Blank + Metal; Blank $=$ Acid + Solvent + Ligand). 
nique. Fig. 3 shows the influence of some solvents on the spectrum of the present system, for a ligand analytical concentration of $200 \mathrm{mmol} \mathrm{L}^{-1}$.

At the employed ligand concentration, most of the solvents provided an increase in the absorbance values. Ethanol was the solvent chosen to continue the comparative studies between the organic and aqueous medium. It is known that acetone, unlike the other solvents, absorbs strongly at wavelengths lower than $320 \mathrm{~nm}$, justifying the high interference and low sign obtained in the spectrum in the presence of this solvent.

In Fig. 4, at a ligand concentration close to that considered ideal in aqueous medium (500 mmol L-1), the presence of ethanol only brought about a small increase to absorbance values, making the aqueous medium the most promising for the accomplishment of the measurements. The use of solvents such as acetone and tetrahydrofuran did not provide the solvatochromic effects for the present chromium(III)/azide system, as observed previously [9-12].

Employing the best conditions of ligand concentration and acidity in aqueous medium (493 mmol L-1 and $12.0 \mathrm{mmol} \mathrm{L}^{-1}$ respectively), with a chromium(III) analytical concentration of only

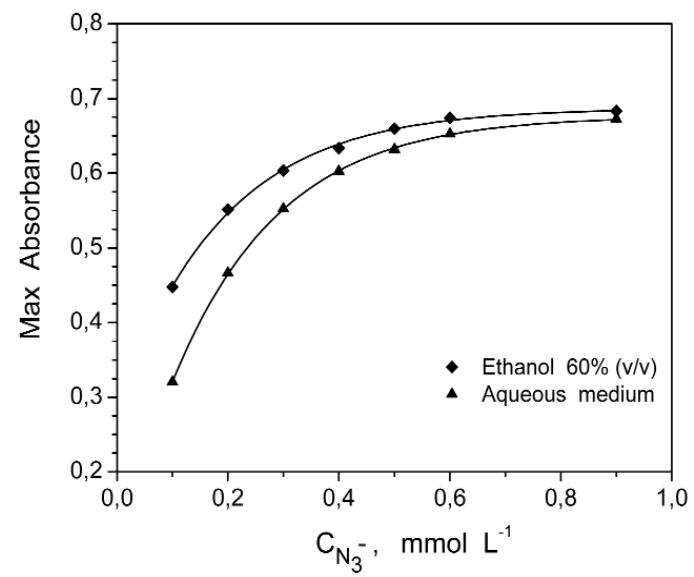

Figure 4. Effect of the ligand analytical concentration on the spectrum of the system in aqueous and organic medium $\left(\mathrm{C}_{\mathrm{Cr}}{ }^{3+}=3.96 \times 10^{-2} \mathrm{mmol} \mathrm{L}^{-1}\right.$; $\mathrm{CHClO}_{4}=12.0 \mathrm{mmol} \mathrm{L} \mathrm{L}^{-1} ; \mathrm{T}=25.0{ }^{\circ} \mathrm{C}$; $\mathrm{t}=1$ hour; Sample $=$ Blank + Metal; Blank $_{(\mathrm{aq})}=$ Acid

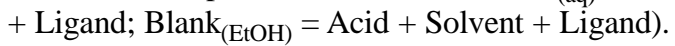

$3.96 \times 10^{-2} \mathrm{mmol} \mathrm{L}^{-1}$, the effect of the temperature and contact time on the formation of the absorbent complex species was verified (Fig. 5). A temperature of $20^{\circ} \mathrm{C}$ provided slow reaction, but led to higher absorbance values for longer contact times, reaching a constant absorbance value after 2 hours, which is too long. Increasing the temperature enabled the system to reach a stable level faster, although a small decrease in the absorbance value was obtained at higher temperatures. This latter fact can be justified by the loss of the azide ligand in the hydrazoic acid (volatile) form. A contact time of 60 minutes at $\mathrm{T}=25.0^{\circ} \mathrm{C}$ showed to be the most promising condition for the accomplishment of the measurements, once at this temperature and reaction time, $98.7 \%$ of the highest absorbance value was reached.

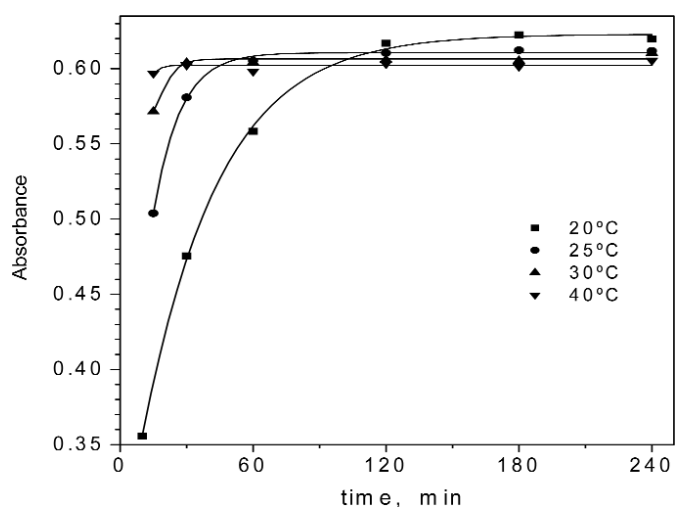

Figure 5. Effect of the temperature and contact time on the absorption measurements carried out at 287 $\mathrm{nm}$.

The absorbance reached a maximum value after a contact time of 360 minutes ( 6 hours Table 1).

Using the most promising conditions (acid perchloric analytical concentration $=12.0 \mathrm{mmol} \mathrm{L}^{-}$ 1 , ligand analytical concentration $=493 \mathrm{mmol} \mathrm{L}^{-1}, \mathrm{~T}$ $=25.0^{\circ} \mathrm{C}$ and contact time $=1$ hour $)$, the analytical curve was obtained from 15 samples. The slope of the straight line obtained from the linear regression supplied a mean molar absorptivity coefficient of $(1.481 \pm 0.008) \times 10^{4} \mathrm{~L} \mathrm{~mol}^{-1} \mathrm{~cm}^{-1}$ for the chromium(III) compounds, with $\mathrm{r}=0.9998$, at $287 \mathrm{~nm}$. 
Table 1. Dependence of the absorbance values on contact time at $\mathrm{T}=25.0^{\circ} \mathrm{C}$, using the ideal acidity and ligand concentration values

\begin{tabular}{ccc}
\hline Time (min) & $\mathbf{A}_{\mathbf{2 8 7}}$ & $\begin{array}{c}\mathbf{A}_{\mathbf{2 8 7}} / \mathbf{0 . 6 1 4} \\
(\mathbf{\%})\end{array}$ \\
\hline 15.0 & $0.499 \pm 0.002$ & 81.3 \\
30.0 & $0.581 \pm 0.002$ & 94.6 \\
60.0 & $0.606 \pm 0.002$ & 98.7 \\
120 & $0.612 \pm 0.002$ & 99.7 \\
360 & $0.614 \pm 0.002$ & 100 \\
1440 & $0.614 \pm 0.002$ & 100 \\
\hline
\end{tabular}

Considering the ideal range of absorbance values between 0.2 and 0.8 , the metal can therefore be determined in the concentration range 0.702 to 2.81 $\mathrm{mg} \mathrm{L}^{-1}$ at $287 \mathrm{~nm}$, using the experimental conditions above established.

Precision studies were accomplished for 20 samples containing $3.96 \times 10^{-2} \mathrm{mmol} \mathrm{L}^{-1}$ (2.06 $\mathrm{mg} \mathrm{L}^{-1}$ ) chromium(III). An absorbance of $0.606 \pm 0.001$ with a confidence limit of $95 \%$ was obtained.

For the interference study, cations (used as nitrates) and anions (used as sodium) salts were added separately to the sample and the results of each of them were compared with the control samples. The conditions for both the control sample and that containing the interfering ion of interest were identical, except for the fact that the control one did not contain the diverse ion. The possible interfering ion was added to the sample in a way that concentrations of $4.0 \mathrm{mmol} \mathrm{L}^{-1}, 2.0$ mmol L-1, $0.40 \mathrm{mmol} \mathrm{L}^{-1}$, or $0.040 \mathrm{mmol} \mathrm{L}^{-1}$ would be obtained in the volumetric flask. These concentrations are equivalent to approximately $100,50,10$, and 1 times the amount of chromium(III) present in the sample. Respectively, the employed conditions of acidity, ligand concentration, temperature, and contact time were the same as the ones pre-estabished with a chromium(III) concentration of $3.96 \times 10^{-2} \mathrm{mmol} \mathrm{L}^{-1}(2.06 \mathrm{mg} \mathrm{L}$ 1) measured at $287 \mathrm{~nm}$. Interference was considered to take place in samples where the error was higher than $5 \%$, considering the real chromium(III) concentration. Of the 30 species stud- ied, $\mathrm{F}^{-}, \mathrm{Cl}^{-}, \mathrm{Br}^{-}, \mathrm{NO}_{3}^{-}, \mathrm{IO}_{3}^{-}, \mathrm{BrO}_{3}^{-}, \mathrm{SCN}^{-}, \mathrm{SO}_{4}^{2-}$, $\mathrm{S}_{2} \mathrm{O}_{5}{ }^{2-}, \mathrm{Li}^{+}, \mathrm{K}^{+}, \mathrm{Mg}^{2+}, \mathrm{Ba}^{2+}, \mathrm{Zn}^{2+}$, and $\mathrm{NH}_{4}{ }^{+}$did not interfere at concentrations that were up to 100 times higher than that of chromium(III). The ions $\mathrm{I}^{-}, \mathrm{NO}_{2}{ }^{-}, \mathrm{CO}_{3}{ }^{2-}, \mathrm{HCO}_{3}{ }^{-}$, and $\mathrm{Mn}^{2+}$ did not interfere at concentrations that were up to 50 times higher than that of chromium(III). The ions $\mathrm{OH}^{-}, \mathrm{S}_{2} \mathrm{O}_{8}{ }^{2-}$ , $\mathrm{H}_{2} \mathrm{PO}_{4}^{-}, \mathrm{HPO}_{4}^{2-}$, and $\mathrm{Cd}^{2+}$ did not interfere at concentrations that were up to 10 times higher than that of chromium(III). The ions $\mathrm{HC}_{8} \mathrm{H}_{4} \mathrm{O}_{4}$ and $\mathrm{Co}^{2+}$ did not interfere at concentrations equal to that of chromium(III). Finally, $\mathrm{Fe}^{3+}, \mathrm{Cu}^{2+}$, and $\mathrm{Hg}^{2+}$ were the most interfering ions $\left(\mathrm{E}_{\mathrm{R}}>5 \%\right)$, even at concentrations lower than that of chromium(III). The $\mathrm{Al}^{3+}$ ion led to sample turbidity, of thus, making the absorbance measurements impossible.

Table 2 shows the results obtained with the nutritional supplement Cromo Chelavite ${ }^{\circledR}$ using the spectrophotometric method developed in this work. The results were compared with those obtained by the atomic absorption technique (Standard addition method), with errors lower than $5 \%$, as seen in Table 3 . The expected value refers to the chromium(III) concentration according to what is stated in the label of the nutritional supplement by the supplier.

In order to verify the validity of the spectrophotometric method and of the proposed previous treatment (section 2.2), a synthetic sample of chromium(III) was prepared from a standardized solution of chromium(III) perchlorate. The synthetic sample was submitted to the same 
Table 2. Mean experimental results and respective error in relation to the expected values for the analysis of the Cromo Chelavite ${ }^{(\mathbb{B})}$ drug

\begin{tabular}{cccc}
\hline \multirow{2}{*}{ Technique } & \multicolumn{2}{c}{$\mathbf{C}_{\mathrm{Cr}}\left(\mathbf{m g ~ L}^{-\mathbf{1}}\right)$} & $\overline{\mathrm{E}}_{\mathrm{R}}(\mathbf{\%})$ \\
\cline { 2 - 3 } & Found & Expected & \\
\hline Spectrophotometry & 1.92 & 2.08 & -7.69 \\
Atomic Absorption & 1.97 & 2.08 & -5.29 \\
\hline
\end{tabular}

Table 3. Mean experimental results and error when compared with Atomic Absorption

\begin{tabular}{ccc}
\hline $\begin{array}{c}\text { Spectrophotometry } \\
\mathbf{C}_{\mathbf{C r}}\left(\mathbf{m g ~ L}^{-1}\right)\end{array}$ & $\begin{array}{c}\text { Atomic Absorption } \\
\mathbf{C}_{\mathbf{C r}}\left(\mathbf{m g ~ L}^{-1}\right)\end{array}$ & $\overline{\mathrm{E}}_{\mathrm{R}}(\%)$ \\
\hline 1.92 & 1.97 & -2.54 \\
\hline
\end{tabular}

Table 4. Comparison of mean results from the prepared, expected, and obtained concentrations using three synthetic samples

\begin{tabular}{ccc}
\hline $\begin{array}{c}\text { Value obtained } \\
\mathbf{C}_{\mathbf{C r}}\left(\mathbf{m g ~ L}^{-1}\right)\end{array}$ & $\begin{array}{c}\text { Value expected } \\
\mathbf{C}_{\mathbf{C r}}\left(\mathbf{m g ~ L}^{-1}\right)\end{array}$ & $\overline{\mathrm{E}}_{\mathrm{R}}(\%)$ \\
\hline 2.08 & 2.06 & +0.971 \\
\hline
\end{tabular}

conditions as the real sample of the nutritional supplement. The ligand was then added under the ideal conditions of temperature and contact time, and measurements were done at $287 \mathrm{~nm}$. Results are in Table 4.

The validity of the proposed method was thus confirmed, with good recovery of the added chromium concentration value. The obtention of good results with the proposed spectrophotometric method and their agreement with the atomic absorption technique (standard addition) in the case of the nutritional supplement Cromo Chelavite ${ }^{\circledR}$ make it a potential way of determining chromium in other products.

\section{Conclusions}

We have developed an aternative method for the analysis of chromium(III) ions that is highly sensitive. This high sensitiveness is due to the use of an interesting absorption band not previ- ously reported in the literature, for the chromium(III)/azide system.

The presence of organic solvents tested in this work did not influence the absorption profile of the chromium(III)/azide system, as had been observed for analogous iron(III)/azide system, mainly in the presence of tetrahydrofuran.

Under the best experimental conditions, absorbance of the chromium(III) complexes were measured at $287 \mathrm{~nm}$, where the molar absorptivity was $(1.481 \pm 0.008) \times 10^{4} \mathrm{~L} \mathrm{~mol}^{-1} \mathrm{~cm}^{-1}$. The system obeyed the Beer's law, and it is suitable for chromium(III) determination over a concentration range of 0.702 to $2.81 \mathrm{mg} \mathrm{L}^{-1}(15-65 \% \mathrm{~T})$. For $100 \%$ stability to be reached, a contact time of 360 minutes (6 hours) was necessary. Of the 30 species investigated in the interference study, $\mathrm{Fe}^{3+}, \mathrm{Cu}^{2+}$, and $\mathrm{Hg}^{2+}$ were the ions that more interfered on the results.

Analytical applications of this method have been successfully tested for the nutritional 
supplement Cromo Chelavite ${ }^{\circledR}$. The results were compared with those from atomic absorption measurements and a very good agrement between these two techniques was obtained.

In conclusion, under ideal conditions and by controlling some possible interference, the proposed method can be precise, accurate and simple.

\section{Acknowledgements}

The authors are grateful to the CAPES for financial support and to Cynthia Maria de Campos Prado Manso for linguistic advices.

Recebido em : 11/09/2006.

Aceito em: 21/11/2006.

L. M. Lourenço, F. G. Martins, V. R. Balbo, A. C. Pimenta, J. R. M. Castro, J. F. Andrade. Estudo espectrofotométrico do sistema cromo(III)/azoteto na região do ultravioleta e seu aproveitamento analítico.

Resumo: Um método sensível e alternativo para a determinação espectrofotométrica de cromo(III) foi proposto. O estudo é baseado na formação dos complexos cromo(III)/azoteto, investigando uma nova banda na região do ultravioleta. As melhores condições experimentais para a determinação analítica deste íon metálico foram: concentração analítica de ligante e ácido perclórico de 493 e 12,0 mmol L-1, respectivamente; meio aquoso, $\mathrm{T}=25.0^{\circ} \mathrm{C}$, tempo de contato $=1$ hora. Nessas condições, o máximo de absorção para o sistema cromo(III)/azoteto ocorreu no comprimento de onda de $287 \mathrm{~nm}$, com um coeficiente de absortividade molar médio de 1,481 $\pm 0,008 \times 10^{4} \mathrm{~L} \mathrm{~mol}^{-1} \mathrm{~cm}^{-1}$, permitindo a determinação deste íon em concentrações cem vezes menores em relação à região do visível. $\mathrm{O}$ sistema obedece a lei de Beer e mostra-se adequado para a determinação de cromo na faixa de concentração de 0,702-2,81 mg $\mathrm{L}^{-1}(15-65 \% \mathrm{~T}$, em uma cubeta de quartzo de 1,00 cm). Aplicações analíticas para o método proposto foram testadas em um suplemento nutricional contendo cromo. Os resultados foram comparados com os da técnica de espectrometria de absorção atômica.

Palavras-chave: cromo; azoteto; azida; espectrofotometria; complexos.

\section{References}

[1] G. O. Chierice, E. A. Neves, Polyhedron 2 (1983) 31.

[2] E. A. Neves, J. F. Andrade, Polyhedron 5 (1986) 717.

[3] N. Coichev, E. A. Neves, Polyhedron 8 (1989) 641.

[4] J. F. Andrade, O. M. Guimarães, Anal. Chim. Acta 271 (1993) 149.

[5] E. A. Neves, J. F. Andrade, G. O. Chierice, Anal. Lett. 18 (1985) 707.

[6] R. Luca, J. E. Bevilácqua, E. A. Neves, J. F. Andrade, Anal. Lett. 20 (1987) 389.

[7] O. M. Guimarães, J. F. Andrade, E. A. Neves, G. O., Chierice, Anal. Lett. 26 (1993) 2491.

[8] D. R. Carmo, J. F. Andrade, O. M. Guimarães, Anal. Lett. 28 (1995) 1897.

[9] C. J. Chacarolli, J. F. Andrade, O. M. Guimarães, V. R. Balbo, C. S. Venezuela, F. S. Teruel, Anal. Chim. Acta 411 (2000) 217.

[10] F. G. Martins, J. F. Andrade, A. C. Pimenta, L. M. Lourenço, J. R. M. Castro, V. R, Balbo, Eclética Química 30 (2005) 63.
[11] A. P. O. Sader, Estudo espectrofotométrico do sistema cobalto (II)/tiocianato e seu aproveitamento analítico. 2002. 91f. Dissertação (Mestrado em Química) - FFCLRP, Universidade de São Paulo, Ribeirão Preto / SP.

[12] A. C. Pimenta, J. F. Andrade, F. G. Martins, L. M. Lourenço. Formação de complexos no sistema ferro(III)/azoteto/tetraidrofurano. 27 ${ }^{\mathrm{a}}$. Reunião Anual da SBQ, Salvador, SBQ, 2004. Resumo QA262.

[13] F. G. Sherif, W. M. Oraby, J. Inorg. Nucl. Chem. 17 (1961) 152.

[14] F. G. Sherif, W. M. Oraby, H. Sadek, J. Inorg. Nucl. Chem. 24 (1962) 1373.

[15] J. C. Templeton, E. L. King, J. Am. Chem. Soc. 93 (1971) 7160 .

[16] L. M. Lourenço, Estudo espectrofotométrico do sistema crômio (III)/azoteto e seu aproveitamento analítico. 2003. 95f. Dissertação (Mestrado em Química) - FFCLRP, Universidade de São Paulo, Ribeirão Preto / SP.

[17] D.C. Harris, Análise Química Quantitativa, Trad. J.A.P. Bonapace e O. E. Barcia, LTC, Rio de Janeiro, $6^{\text {a }}$ ed.,2005, apêndice G, p.793. 